\title{
THE IMPORTANCE OF THE SERMON AND THE PREACHER'S RESPONSIBILITY, ACCORDING TO ARCHIMANDRITE IULIU SCRIBAN
}

\author{
Prof. Ph.D. Nicușor BELDIMAN, \\ "Faculty of Orthodox Theology „Justinian Patriarch”, University of Bucharest, \\ ROMANIA, \\ E-mail: prnbeldiman@gmail.com
}

\begin{abstract}
In his homiletic writings, the author illustrates the significance that speech has in preaching the Word of God and he describes it as the tool with which the priest fulfills the mission he was given by his Savior, to preach His Gospel to the world. Father Iuliu Scriban insists on several traits that characterize church language, stressing the idea that the Church has established very precise forms for expounding the truths of faith, for the use of the revealed Word. Thus, words must be the most suitable in respect with their contents; they must convey God's will. He recommends that words without any impact or words that carry no emotion, no suggestive value, no authority, should be avoided.
\end{abstract}

Keywords: Archimandrite Iuliu Scriban; prestigious preacher; sermon; realism; homiletic writings; sermon for children;

\section{PRELIMINARY CONSIDERATIONS}

Being sensitive to all the great aspirations of his time and integrating himself fully into the age in which he was living, Archimandrite Iuliu Scriban tried to suggest answers to the major problems of life by relying on Christian teachings, seeking to enlighten and instill morale in the society to which he belonged. He "guided, he led the way but at the same time he fought, he debated". He was the Church's spokesman in all social, cultural and religious matters of his time, "guiding, and teaching with conviction and wisdom". As a priest, he served in the Romanian Chapel in Baden-Baden and at the "Kalinderu" Church in Bucharest, where he carried out his mission with remarkable dignity, celebrating the liturgical services with piety and warmth, but above all, preaching zealously, with talent and passion, as a prestigious preacher.

Using ample gestures and his pleasant baritone voice, he delivered his sermons in a pure Romanian language, making deeply insightful commentaries and giving convincing examples $^{2}$. His speeches were enjoyed by educated people and by the less educated alike. He preached so extensively that "if he had written on paper all his sermons and speeches, hundreds of volumes would have been created". He spoke with ease and fluency, and he was gifted with the rare skill of improvisation. He was unique in interpreting the nature of

\footnotetext{
${ }^{1}$ Pr. Nicușor Beldiman, Predica în Biserica Ortodoxă Română din Muntenia în secolul al XX-lea - Analiză și evaluare (The Sermon in the Romanian Orthodox Church from Muntenia in the XX th Century. Analysis and Evaluation), University of Bucharest, 2017, p. 102.

${ }^{2}$ Ibidem.
} 
contemporary life down to the most insignificant fact, and this gave his sermons realism and a great power of attracting the audience" 3 . He was born on May $31^{\text {st }}, 1878$ in Galaţi and attended the Theological Seminary in Galaţi, "Veniamin" Seminary in Iaşi and the Faculty of Theology in Bucharest (1898-1902), obtaining his degree in 1903 and his Ph.D. in 1920. He was tonsured into the monastic life at the Neamt monastery (1904), ordained as hiero-monk and superior of the Romanian Orthodox Chapel in Baden-Baden (1904-1909). During this time, he attended the courses of the Faculty of Catholic and Protestant Theology in Strasbourg, and the Faculty of Philosophy in Heidelberg. He was promoted to the rank of Archimandrite by Metropolitan Iosif Gheorghian. On his return to the country, he was appointed Headmaster of the Central Seminary in Bucharest (1909-1919), and continued there as a professor until 1928. He then became a professor of Homiletics and Pastoral Theology at the Faculty of Theology in Chişinău, and was later transferred to the Faculty of Theology in Bucharest (1941-1943). He participated in many different ecumenical and interOrthodox meetings abroad: the Inter-Orthodox Conference on the matter of the calendar (Constantinople, 1923), the World Conference on Practical Christianity (Stockholm, 1925), the Congress of Orthodox Theology Professors held in Athens (1936).

He published textbooks for seminaries, homiletic, pastoral and apologetic studies, volumes of sermons, devotional books, hundreds of articles, translations, notes, and reviews in the Church magazines: Pentru limbă şi ţară (For the language and the country), Bucharest, 1916; Chemarea preotului. Studiu îndrumător pentru activitatea pastorală a preotului (A Priest's Calling. A Guidebook for the Priest's Pastoral Activity), Bucharest, 1921; Studiul Pastoralei în Biserica românească (Study on the Pastoral Work in the Romanian Church), Sibiu, 1924; Privelişti din câmpul Omileticii (Considerations on Homiletics), Bucharest, 1929; Un predicator francez: Père Brydaine (A French Preacher: Père Brydane) (1701-1767), Bucharest, 1933; Datoria preotului către limba bisericească (The Priest's Duty towards the Church language) Sibiu, 1938; Patruzeci de predici populare (Forty sermons for the People), $1^{\text {st }}$ edition, Bucharest, 1904; Cincizeci de predici populare (Fifty sermons for the People), $2^{\text {nd }}$ edition, Vălenii de Munte, 1908; Şaizeci de predici populare (Sixty sermons for the People), $3^{\text {rd }}$ edition, Vălenii de Munte, 1913; Predici pentru popor (Sermons for the People), $4^{\text {th }}$ edition, Bucharest, 1944; Originea Duminicii ca $z i$ de sărbătoare în Biserica creștină (The Origins of Sunday as a Holy day in the Christian Church), Bucharest, 1921; Invăţătura crucii sau alfabetul creștinului (Teachings of the Cross or a Christian's Alphabet), Bucharest, 1922; Tâlcuirea Sfintelor Evanghelii a celor patru evanghelişti (Interpretation of the Holy Gospels of the four Evangelists) Chişinău, 1931; Cartea cărţilor: Sfânta Scriptură sau Biblia (The Book of Books: The Holy Scripture or the Bible), Bucharest, 1937.

As a Theology professor, he kept his students informed about everything that was being published in the literature on the subjects he was teaching, about all the movements and theological currents developing abroad. His Pastoral Theology courses were interesting and educational, because in his youth he had been concerned with the study of the Pastoral Theology and his discourses were informed by his rich pastoral experience ${ }^{4}$. When teaching Homiletics, he didn't simply address the homiletic principles within the limited framework of the course, but instead presented the profiles of a series of Christian preachers such as:

\footnotetext{
${ }^{3}$ Pr. Grigorie Cristescu, Părintele arhimandrit Iuliu Scriban (Father Archimandrite Iuliu Scriban), in „,G.B.”, year VIII (1949), no. 1-2, p. 111.

${ }^{4}$ Pr. prof. Ioan Constantinescu, Arhimandritul Iuliu Scriban (Archimandrite Iuliu Scriban) (1878-1949), in „S.T.”, year XXVIII (1976), no. 7-10, p. 740.
} 
Franck Thomas, Spurgeon, Filaret, Zocchi, Robertson, Père Samson, as well as some of their sermons, as sources and examples for the speeches delivered in the church. By understanding the role and noble purpose of sermon, he advocated outside the academic circles, in various articles, for restoring the sermon to its rightful leading role in a priest's activity. He had a true calling for spreading the Word of God and he was evidently well prepared and well-endowed for this mission ${ }^{5}$.

In his homiletic writings, the author illustrates the significance that speech has in preaching the Word of God and he describes it as the tool with which the priest fulfills the mission he was given by his Savior, to preach His Gospel to the world. Father Iuliu Scriban insists on several traits that characterize church language, stressing the idea that the Church has established very precise forms for expounding the truths of faith, for the use of the revealed Word. Thus, words must be the most suitable with respect of their contents; they must convey God's will. He recommends that words without any impact or words that carry no emotion, no suggestive value, no authority, should be avoided.

\section{A FRENCH PREACHER: JACQUES BRYDAINE (1701-1767)}

Information about this brochure is provided in its foreword, where the author tells us that it is part of a small collection of studies published for the benefit of his students at the Faculty of Theology in Chişinău ${ }^{6}$. The book includes two articles, namely: Viaţa şi lucrarea lui Jacques Brydaine (The Life and Works of Jacques Brydane), first published in Păstorul Ortodox (The Orthodox Shepherd) review, and respectively: De ce nu predicăm şi de ce predicăm slab? (Why we fail to preach, or we preach poorly), first published in Viitorul (The Future) review.

The author presents the biographical data of the preacher Jacques Brydaine highlighting several significant aspects of his life: he began his preaching activity in 1725 when he was ordained as priest; as a missionary he "traveled across France, preaching everywhere he went" ${ }^{\text {" }}$, during his 256 missionary journeys. Due to his fervor for Christian sermon, his activity remains as an important page in the history of the great Christian preachers.

What established him as a consecrated preacher was his speech of 1753 , delivered in the Saint-Sulpice Church in Paris. There were voices claiming that the introductory part of this sermon does not belong to Father Brydaine, because it was improved over time ${ }^{8}$. Upon examining several sermons of Father, Archimandrite Scriban ascertains that this introduction is indeed entirely the author's: "having read his sermons, we assert that the introductory part in question is in full agreement with the usual tone and ardor of Brydaine" ${ }^{\text {. }}$. The author further highlights a detail about the preacher's speeches, namely that he did not prepare them beforehand, and in spite of this, they were very well put together, proving an incredible mastery of the discourse. Finally, we are presented with the famous introduction of the 1753 sermon and with another speech on the topic of forgiveness of one's enemies.

\footnotetext{
${ }^{5}$ Pr. prof. dr. Constantin Galeriu, Catedra de Omiletică şi Catehetică cu noţiuni de Pedagogie, in ,S.T.”, year XXXIII (1981), no. 7-10, p. 580.

${ }^{6}$ The two articles in this brochure are part of the course entitled Chipurile cele mai de seamă ale cuvântării creştineşti (The most important figures of Christian sermon) at the department of Homiletics of the Faculty of Theology in Chişinău.

7 Arhim. Iuliu Scriban, Predicatorul francez Jacques Brydaine (French Preacher Jacques Brydaine), „Astoria” Printing Press, Bucharest, 1933, p. 8-9.

${ }^{8}$ Ibidem, p. 10-11.

${ }^{9}$ Ibidem, p. 15.
} 
In the second part of the brochure, the author speaks about the sermon by answering two questions: Why do we fail to preach? and Why do we preach poorly? Paradoxically, the Church was born through preaching, and yet, hundreds of years later, there is almost no preaching going on anymore. During the early centuries people were not so educated, so preaching was performed as best possible. Later, the Church noticed how the preaching activity was becoming more and more scarcer and took a stand: canon 58 of the Apostolic Council $^{10}$, canon 19 of the Sixth Ecumenical Council ${ }^{11}$. There should be more preaching, said Archimandrite Iuliu Scriban: "failure to preach is tantamount to denying the Church, because when you say Church you say preaching, teaching. At its very core lies the act of preaching" $"$.

To answer the question Why do we fail to preach?, the author gives a simple and forthright reason: "because there is no love" 13 . If the priest truly loves his flock, he shall preach, he shall open the minds of people and show them where they err. In addition, the author draws attention to another aspect, namely the need to defend the Church, because "one hears so many unfair accusations against the Church that it is impossible not to feel pain in our heart and not come to its defense"14. Finally, the author addresses the weak points, showing that the amount of preaching is rather insufficient: "we boast about the great number of sermons delivered today in Romania. Actually there are not that many, but to be truthful, there are really very few; the pulpits are silent, most of the time" ${ }^{\prime 15}$. Rarely can one find a good sermon, and the reason is that the sermon is delivered not out of love, but out of duty. To make a good sermon, you need to prepare thoroughly, because "without preparation, the sermon cannot come together as a whole"16. Archimandrite Scriban lays particular emphasis on the special preparation of the sermon.

Accepting the risk of being criticized, the author revealed these flaws of the Romanian sermon, hoping that in the future priests would show more zeal in their service and would pay more attention to the moment of preaching, remembering the Savior's commandment "Go and teach all nations..." (Matthew 28, 19).

This shows the importance Iuliu Scriban assigns to the sermon, but also his interest in the foreign preachers that may set examples for us.

\footnotetext{
10 "If any bishop or presbyter neglects the clergy or the people, and does not instruct them in the way of godliness, let him be excommunicated, and if he persists in his negligence and idleness, let him be deposed." (Archdeacon prof. dr. Ioan N. Floca, Canoanele Bisericii Ortodoxe, Note şi comentarii (Canons of the Orthodox Church, Notes and commentaries), 3rd edition, improved, Sorin Joantă ed., Sibiu, 2005, p. 40). As the Savior commanded, Go and teach all nations.. (Matthew 28, 19), priests and bishops have the duty to teach the believers about the Orthodox faith. For this purpose, the clergy must preach and catechize the believers.

11 "We declare that the deans of churches., on every day, but more especially on Sundays, must teach all the

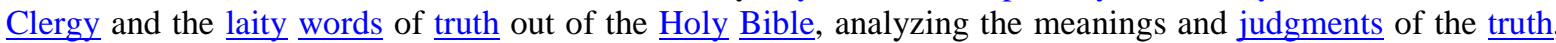
and not deviating from the definitions already laid down, or the teaching derived from the God-bearing Fathers; but also, if the discourse be one concerning a passage of Scripture, not to interpret it otherwise than as the

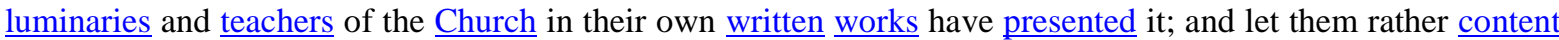
themselves with these discourses than attempt to produce discourses of their own, lest, at times, being resourceless, they overstep the bounds of propriety)..." (Arhid. prof. dr. Ioan N. Floca, Canoanele Bisericii Ortodoxe (Canons of the Romanian Orthodox Church)... p. 128). Through this canon bishops and priests have the obligation to preach especially on Sundays but when they prepare the sermons they need to do it in the spirit of the Holy Fathers, following their guidance in order not to fall in error.

${ }^{12}$ Arhim. Iuliu Scriban, Predicatorul francez Jacques Brydaine..., p. 2.

${ }^{13}$ Ibidem, p. 2-3.

${ }^{14}$ Ibidem, p. 6.

${ }^{15}$ Ibidem, p. 8.

${ }^{16}$ Ibidem, p. 9.
} 


\section{CONSIDERATIONS ON HOMILETICS ${ }^{17}$}

In 1928 he was appointed the position of Professor of Homiletics at the Faculty of Theology in Chişinău. In addition to the notions he taught his students, he worked to create a textbook as study material for the course, thus reviving the subject of Homiletics: "Until now the principles of Homiletics used to be taught according to a set of rules that were entirely unappealing to those learning them and from which they hardly derived any benefit. Archimandrite Scriban has widened the horizon of the Homiletics field, has laid new bases and sowed rich seeds that are beginning to ripe into usefulness. He made the homiletic material richer, he interpreted its principles, and he made the representatives figures of sermon well known to any theologian"18.

The book presents articles published in the Biserica Ortodoxă Română (Romanian Orthodox Church) review. The textbook has 178 pages, grouped in 14 chapters. We mention the essential ideas in each chapter.

Old Romanian Homiletics ${ }^{19}$. In the beginning the author remarks that the first to appear were the sermons and then the books/textbooks on how sermons can be produced. The first compilations of sermons appeared in the $16^{\text {th }}-17^{\text {th }}$ centuries (Cazaniile [Sermon Books], the Kiriakodromion), while treatises on Homiletics appeared much later, in the $19^{\text {th }}$ century. He then examines and highlights the essential parts of the Homiletics treatises. The first published work was entitled: Teologia pastorală sau datoriile preoţilor (Pastoral Theology or the Priest's Duties) and was a Russian treatise written by hierarchs Gheorghe Coninski and Partenie Sopkovski in 1776, translated and published in Romanian in 1817. The first Romanian Homiletics work belongs to Archimandrite Teoctist Scriban - Omiletica sau Ştiinţa despre literatura bisericească (Homiletics or the Science of Church Literature), Iaşi, 1856, followed by a second volume in 1857 . Upon examining the book, the author notes that it is more than just a homiletics textbook because "the teachings imparted by this book is purely Christian"20. Archim. Scriban recommends this text because it offers solutions and points of view concerning the fight against sects. Omiletica (The Homiletics) by Dionisie Romano, Principii de Retorică şi Elokuinţa Amvonului (Principles of Rhetorics and Eloquence at the Pulpit) (Iaşi, 1859) is, as the title indicates, a book on rhetorics rather than on Homiletics as such. It is divided into: "rules of general oratory... common classification of rhetorics, with approaches on syllogisms, dilemmas, inductive reasoning and others" ${ }^{\text {21 }}$. He translates and presents the section on church language in the book entitled Lecons de Litterature by Ulysse de Marsillac, published in Bucharest in 1859. It is a short list of homiletic principles which Archimandrite Scriban considers important because it is offered not by an expert but rather by a teacher of French literature. This is what he mentions at the end of this presentation: "So we had amidst us, though not in our own language, a brief but beautiful presentation of homiletics, a study well put together; its discovery brought us great joy and with the same joy we share it with our readers and with those who are drawn to homiletic studies"22.

\footnotetext{
${ }^{17}$ The Printing Press of Church Books, Bucharest, 1929.

${ }^{18}$ Ierom. Vasile Vasilache, Arhimandritul Iuliu Scriban (Archimandrite Iuliu Scriban), in „M.M.S”, anul XXV (1949), nr. 1-2, p. 236.

${ }^{19}$ Arhim. Iuliu Scriban, Vechile Omiletici româneşti (The Old Romanian Homiletics), in „B.O.R.”, year XLVI (1928), no. 7, pp. 613-623.

${ }^{20}$ Idem, Privelişti din câmpul Omileticii (Considerations on Homiletics), the Printing Press of Church Books, Bucharest, 1929, p. 9.

${ }^{21}$ Ibidem, p. 12.

${ }^{22}$ Ibidem, p. 24.
} 
The Sermon Today ${ }^{23}$. The author notes that preaching is scarce and tries to find out the cause, but also to offer solutions. This is what he says: "The blame is to be placed on the very contents of the sermon, on the method used, on its shift from a living event, as is expected of the preacher who should pour his soul out to his followers, into a mere piece of standardized work" ${ }^{24}$. Archimandrite Scriban also finds that the audience has changed: people are no longer religious, they no longer come to the church, and priests have to speak to them as they would to pagans and to ignorant. That means that preaching work will become easier since "we will no longer deal with important matters extensively, nor choose those that are the most difficult, but rather start from the beginners' level... talk in a language that is simple and comprehensible..." 25 . At the same time, he gives examples of priests and bishops who were concerned with the sermon: Metropolitan Partenie of Moldavia who even sent a pastoral letter asking priests to preach regularly in the church. Other bishops who were concerned with the sermon were Ghenadie Petrescu and bishop Atanasie of Râmnic.

As rev. prof. David Pestroiu asserted, "we can still distinguish between preaching and dialogue. They both have the same purpose: spreading the Truth, but they are different in shape and content. The preaching can also be a monologue and has as the single point of order the words from the Holy Bible. Instead, the dialogue knows a much higher plate of meanings and approaches, in regard to different functions of language and also to context of pluralism, industrialization and globalization",26

Is sermon wanted? Because preaching had not been done all the time, it had become an oddity in some parishes. Scriban even asserted that parishioners did not know that the sermon is a liturgical act. There were, however, people who were aware of the importance of the sermon. One of them was Prince Barbu Dimitrie Stirbei, former minister of Religious Affairs, who proposed to establish seminaries where the future priests would be trained so that they could speak to all Romanians everywhere. Another advocate of preaching was Minister Grigore Paucescu, who wanted "churches to offer teachings too"27. The same stance was taken by Bishop Iosif Gheorghian of Galaţi and by Gh. D. Mugur, who wrote two articles on the importance of sermon in the "Universul" newspaper in 1927.

A great figure of the Orthodox preaching. As soon as he became a professor at the Faculty of Theology in Chişinău, he showed an ardent desire to make personalities of sermon known to the world. One of them was Archbishop Innocent of Odessa and Herson. He published his sermons in a journal that was highly demanded, and even founded his own review - Citirea Duminicală (Sunday Readings).

Oral or written preaching? Pope Leon XIII once said: Our newspapers will reach places where your sermons do not. Taking this dictum into consideration, the author shows that a written sermon is also a means of catechizing the people. Just as a written sermon is difficult to put together, so is the spoken one, because in a matter of minutes you need to summarize what you want to convey. However, he draws attention to the fact that we should prefer preaching orally, "because what does man do more readily? Talk or read?"28. It is easier to listen than to read. The author is right when he asserts that written sermons will not be widely read.

\footnotetext{
${ }^{23}$ Idem, Predica în ziua de azi (Sermon Today), în „B.O.R.”, anul XLVI (1928), no. 10, p. 896-909.

${ }^{24}$ Idem, Privelişti din câmpul Omileticii (Considerations on Homiletics)..., p. 26.

${ }^{25}$ Ibidem, p. 30.

${ }^{26}$ David Pestroiu, Religious Dialogue in Postmodernity - Necessity, Chances, Perspectives, in „International Journal of Orthodox Theology", no. 4:1 (2013), p. 154.

${ }^{27}$ Arhim. Iuliu SCRIBAN, Privelişti din câmpul Omileticii (Considerations on Homiletics)..., p. 40.

${ }^{28}$ Ibidem, p. 59.
} 
Another great figure of Orthodox sermon: Metropolitan Philaret of Moscow. Archimandrite Scriban considers Metropolitan Philaret of Moscow the most important $19^{\text {th }}$. century personality of the Russian Church. Referring to the sermons of the Russian Metropolitan, Archimandrite Scriban states that "in addition to their theological significance, there are some that are fruitful and enlightening through the very national language " 29 . After a brief review of the important moments in the Metropolitan's life, the author presents some of the characteristics of his sermons.

Challenges faced in preaching. In this chapter the author addresses another challenge that the sermon meets: free preaching. In history there have been great preachers who had difficulties in learning the sermon by heart. Some stopped preaching out of fear of making fools of themselves by stumbling right in the middle of their speech. To avoid this problem, the author believes that the sermon must be thoroughly prepared: "What is prepared down to the smallest detail is better than what is left to the spur of the moment" 30 . Here is what the author recommends as a solution for a successful sermon: "The plan must be carefully thought out, revised, chiseled here, and mended there, so that in the end you will hold in your hands a beautiful piece of work. Your next step is filling with material each part of the plan that is clothing each characteristic in ideas, so that what results from this is an entirety perfectly bound together. This means putting on paper the entire chain of ideas, like something that grows step by step from your mind. Once you have done this as well, you need to go on further and search for ways in which you could utter what you have worked. From here you will struggle with the text that you created, to master its ideas. In order to voice them, you need to have them in mind, so that you will be able to utter them easily" 31 .

By the power of the mind or the grimaces of the face? Another foreign preacher is presented here, namely the Franciscan monk Agostino da Montefeltro. As is his custom, the author provides some biographical information, followed by an examination of his preaching manner. What can be remarked here is the fact that the author highlights the weaknesses in the speech of the above-mentioned monk, namely: the sermon must resemble a discourse from within the Church, not from without; by using these means of the outside world, "he did not manage to attain what should have been the aim of the sermon: to turn man's will towards God"32; speaking too fast ${ }^{33}$ or the contrary - speaking too slowly. In the end, Archimandrite Scriban also presents one of the monk's sermons, namely an approach to Cinstirea sărbătorilor (Observance of Holidays), uttered on the occasion of the 1889 Lent.

Preacher Gaetano Zocchi. We tend to believe that Archimandrite Scriban presented the Jesuit Gaetano Zocchi for the purpose of evidencing another threat to sermon - the exaggerated use of physical movements, namely mimic and gestures. The author explains: "it is not recommended that the man stand completely still, while speaking... on the other hand, nor should he be gesturing excessively" $"$.

Preachers of today. Archim. Scriban believes that the person who extended the borders of Homiletics studies was Metropolitan Nectarie of Bukovina who, in his work entitled Trepte formale în predică (Formal steps in sermon) (Cernăuţi, 1923) approached

\footnotetext{
${ }^{29}$ Ibidem, p. 68.

${ }^{30}$ Ibidem, p. 75.

${ }^{31}$ Ibidem, p. 77-78.

${ }^{32}$ Ibidem, p. 88.

${ }^{33}$ The monk Agostino held the record of the fastest speaker. The newspapers of those times wrote that he would exceed 150 words per minute.

${ }^{34}$ Arhim. Iuliu SCRIBAN, Privelişti din câmpul Omileticii (Considerations on Homiletics)..., p. 104.
} 
issues that had not been dealt with until then. After a brief review of the most famous preachers, the author stops at the French preacher Père Samson. As usual, the author provides us with a model of the most representative sermon of this French preacher. The speech is the first of a series of 7 sermons delivered in 1925. The one presented here is entitled Invăţătura noastră: Iisus Hristos şi Iisus Hristos răstignit (Our teaching: Jesus Christ and Jesus Christ crucified), uttered in the presence of Cardinal Dubois and of three other bishops at the Notre-Dame Cathedral in Paris.

Poorly prepared sermons ${ }^{35}$. Archimandrite Scriban thinks that many people are able to speak without having a text to read from or without preparing beforehand. The success of a discourse lies in thinking it through because "the whole foundation is not the spoken word, but what lies inside it, namely the thought" $"$. The mistake people make is that they believe that the spoken word is everything and if the spoken words flow easily, the speech can be considered successful. That is why they should not open their mouth before thinking about what they are going to say, nor should they say anything or believe that if the spoken words flow easily, then everything else is also right. Rather than having spoken words pour out, people should care more for deep and clear thinking, because if their mind is clearly structured, then thought is easier to put into speech, even when you are not accustomed to speaking. "It is better to put some thought into what you say rather than just utter words in which you have not yet accustomed yourself to pour any meaning" "37. To speak should mean to think. When you start speaking, first you must think about what you intend to say. Don't let yourself be carried away by the hope that language will work by itself and that you will easily be able to come up with random words. We must beware of words uttered uselessly, words that not have been thought out, words that have not been reflected upon, because to really say something, it takes more than just opening your mouth"38.

He who starts speaking without preparation has an even greater duty to have a background of deeper, fuller preparation, a strong culture, and strong principles, rich experience and knowledge, on which he can rely when necessary. Preparation is always needed. "There is no water springing if there is no reservoir, and just like water will never climb higher than the height of the spring it came from, man will never reach higher than the training he possesses" 39 . The unprepared speaker must write more, particularly in the beginning. By writing, you learn to speak. Just by speaking, you can only say what you have said before and you will see your horizon narrowing more and more, precisely when you want to expand it. The ability to think and speak is acquired through precise, carefully and persistently researched work, and this you cannot get from the spoken word alone. To be able to have many words at hand, and a treasury of well-tailored and enlightened speeches, the same diligence is necessary". 40

As for the contents of the discourse, the control through writing is unavoidable. Nobody can think straight if he cannot write. You should always fear the unclear speech, because the speech reveals its own flaws. With writing you are more careful and expect more

\footnotetext{
${ }^{35}$ Idem, Dacă am vorbi pe nepregătite (If we speak unprepared) in „B.O.R.”, year XLVIII (1930), nr. 2, p. 130-139.

${ }^{36}$ Idem, Privelişti din câmpul Omileticii (Considerations on Homiletics )..., p.131.

${ }^{37}$ Ibidem.

${ }^{38}$ Ibidem, p. 132.

${ }^{39}$ Ibidem, p. 141.

${ }^{40}$ Ibidem.
} 
from your work, while he who improvises a speech misguides himself with words that only conceal his flaws ${ }^{41}$.

Further on we find the opinion of Archbishop Ambrosius of Harkov about unprepared speech, as well as an article of the French preacher A. de Sertillanges.

A man who loved the sermon: Constantin Câță Nicolescu. The author presents this preacher as a "a man in love with sermon" 42 . We are introduced to his ideas on the significance of sermon and the power of the word. Archimandrite Scriban recommends the examples offered by Câță Nicolescu "to any young man who is learning the art of mastering speech",43.

Sermons for children ${ }^{44}$. An interesting fact is that the author reserves a special place in this textbook to the sermons for children. "The sermon for children stands next to the sermon for the grown up" $" 45$. The sermon intended for children first appeared in England in the 1870s-1880s. Not any preacher can deliver a discourse to children because it is no easy task to talk to children. On the other hand, it is difficult to step down from your level of thinking to make your message understood by children.

The sermon broadcast on the radio. The author offers us some very interesting information, namely that in his time it was already possible to preach on the radio. These sermons were subsequently put in writing, and thus an entire radiophonic literature was born. However, it is one thing to speak to people standing right in front of you, and another thing to preach in their absence. Archimandrite Scriban concludes that "the radio-delivered sermon must be much more fluent in terms of speech so that it is understood by all" ${ }^{\prime 4}$. Its language must be as simple as possible, without too many turns of phrases or subtleties in thinking; sentences must be short so as to meet this need as much as possible, and the length must be shorter than in the case of other sermons. The sermon delivered on the radio is heard by a larger audience than in a church. That is why the radiophonic speech must flow easily so everybody understands it. On the radio it is not appropriate to deliver very deep speeches. Although meant for people so spread out and far away, they must be friendly, as if the preacher were talking to the listeners face to face.

"The sermon broadcast on the radio - says the author - those who are ill can hear it from their hospital beds. It is particularly for them that the sermon is of great comfort. As for those who are in prisons, speeches aired on the radio constitute a great and pleasant novelty. For this reason, the messenger of God must be happy that he has such preaching means available to him, when only the preaching in the church is not enough. Now, that we have this tool, all we need to do is use it!"47.

Finally, he presents a model of a radio sermon. Following the examination of these works, we can conclude that it is a very good textbook for the subject that he was teaching, especially due to the fact that it contained unusual chapters such as: Challenges faced by the sermon, Poorly prepared sermons, Sermons for children etc., all these remarks being described in his characteristic style, wise and moralizing.

\footnotetext{
${ }^{41}$ Ibidem.

${ }^{42}$ Ibidem, p. 148.

${ }^{43}$ Ibidem, p. 150.

${ }^{44}$ Idem, Predica pentru copii (Sermon for children), in „B.O.R.”, year XLIX (1931), no. 5, p. 422-427;

Evanghelizarea copiilor (Gospelizing children), in „B.O.R.”, year XLII (1924), no. 10, p. 602-604.

${ }^{45}$ Idem, Privelişti din câmpul Omileticii (Considerations on Homiletics)..., p. 159.

${ }^{46}$ Ibidem, p. 172.

47 Ibidem, p. 167.
} 


\section{A PRIEST'S DUTY TOWARDS THE LANGUAGE OF THE CHURCH ${ }^{48}$}

The priest is an educated man. We can make him better understand the beautiful gift that the Church is given through the language it has worked with over time in the midst of its people. That is why it is very relevant to talk about the Church's language today. The priest, having the duty to protect the people from the many foreign infiltrations in its midst, needs to realize this and take upon himself to carry out the duty concerning "the language of old". By doing so, the priest shall be a soldier without sword and rifle, but defending fully and truthfully this valuable heritage of the past that is our language, from the days of Trajan up to the present ${ }^{49}$.

In the language of church books, we find a treasure that must be cherished and used. No matter how full of Slavic terms it may be said to have, let us think that in it we find the first attempts of transposing thoughts into the language of the people, a task that was not at all easy. Just as Luther's Bible was treasured by his people, because it meant comprising the German language in writing, so the language in our church writings is "the common bond we all share, as a body of people" speaking the same language on the Romanian land ${ }^{50}$.

\section{CONCLUSION}

As can be noted from everything presented here, Archimandrite Prof. Iuliu Scriban believed that sermon has an extremely important role in the pastoral mission. However, it must not be separated from the context of a life lived responsibly, and during which other missions also require to be carried out. Preaching the word is one of the greatest duties a priest has towards those he shepherds and all this must be in harmony. A true sermon is always in the spirit of the liturgical, architectural and iconographical ministry of a church. The Holy Liturgy prepares the believers for receiving the word of teaching. During the Liturgy, believers are much more willing to listen to a sermon. The sermon or homily, whatever the genre, completed later by the catechesis, have been and still are mandatory parts of the Holy Liturgy. The sermon is not optional, but rather an important moment in the mandatory ritual of Holy Liturgy. That is why we cannot conceive the Holy Liturgy without sermon or teachings.

A speech isolated from the Liturgy may generate in the listener a misguided sensation of knowledge of God. Thus, one may come to mistake the Gospel for the intellectual comprehension of faith, accompanied by a set of moral rules. As for the person who is preaching, his discourse, no matter how well built oratorically, if it is apart from the church, if it does not subscribe to the liturgical reality, then it is not a sermon, but rather, it becomes a personal act of the preacher.

\footnotetext{
${ }^{48}$ Sibiu, 1938.

49 Arhim. Iuliu Scriban, Datoria preotului către limba bisericească (Priest's duty towards the language of the church), Sibiu, 1938, p. 14, 29.

${ }^{50}$ Ibidem, p. 23.
} 


\section{BIBLIOGRAPHY:}

[1] Beldiman, Nicuşor, Predica în Biserica Ortodoxă Română din Muntenia în secolul al XX-leaAnaliză și evaluare, University of Bucharest, 2017.

[2] Constantinescu, Ioan, Arhimandritul Iuliu Scriban (1878-1949), in „S.T.”, year XXVIII (1976), no. 7-10.

[3] Cristescu, Grigorie, Părintele arhimandrit Iuliu Scriban, in „G.B.”, year VIII (1949), no. 1-2.

[4] Galeriu, Constantin, Catedra de Omiletică şi Catehetică cu noţiuni de Pedagogie, in ,S.T.”, year XXXIII (1981), no. 7-10.

[5] Pestroiu, David, Religious Dialogue in Postmodernity - Necessity, Chances, Perspectives, in „International Journal of Orthodox Theology”, no. 4:1 (2013).

[6] Scriban, Iuliu, Dacă am vorbi pe nepregătite, in „B.O.R.”, year XLVIII (1930), no. 2.

[7] Scriban, Iuliu, Evanghelizarea copiilor, in „B.O.R.”, year XLII (1924), no. 10.

[8] Scriban, Iuliu, Predica în ziua de azi, în „B.O.R.”, year XLVI (1928), no. 10.

[9] Scriban, Iuliu, Predica pentru copii, in „B.O.R.”, year XLIX (1931), no. 5.

[10] Scriban, Iuliu, Predicatorul francez Jacques Brydaine, „Astoria” Printing Press, Bucharest, 1933.

[11] Scriban, Iuliu, Privelişti din câmpul Omileticii, the Printing Press of Church Books, Bucharest, 1929.

[12] Scriban, Iuliu, Vechile Omiletici româneşti, in „B.O.R.”, year XLVI (1928), no. 7.

[13] Scriban, Iuliu, Datoria preotului către limba bisericească, Sibiu, 1938.

[14] Vasilache, Vasile, Arhimandritul Iuliu Scriban, in „M.M.S”, year XXV (1949), no. 1-2 